Article

\title{
Bioaerosol in Composting Facilities: A Survey on Full-Scale Plants in Italy
}

\author{
Elisa Anedda *(D) and Deborah Traversi (D) \\ Department of Public Health and Pediatrics, University of Torino, 10126 Torino, Italy; deborah.traversi@unito.it \\ * Correspondence: elisa.anedda@unito.it; Tel.: +39-011-6705-703
}

Received: 11 February 2020; Accepted: 15 April 2020; Published: 16 April 2020

check for updates

\begin{abstract}
Bioaerosols lead to human health diseases and composting plants are one of the main sources among human activities. In this study, a survey was conducted on such plants to evaluate bioaerosol risk management. A questionnaire was used to collect information on plant location, process types, collective and personal protective equipment, bioaerosol and particulate matter monitoring data, and occupational surveillance. We examined the data produced by 11 plants located in Italy. Self-control bioaerosol monitoring showed a global contamination index mean of $9908 \mathrm{CFU} / \mathrm{m}^{3}$ underlining a higher concentration (a) in plants with only aerobic process (CPs) with respect to plants that also combined anaerobic treatment of the waste (ADCPs) $(p<0.05)$ and $(b)$ in facilities with biocells with respect to windrows $(p<0.01)$. Workers are generally more exposed when working without vehicles. Some areas such as pre-treatment and screening are more prone to higher bioaerosol concentrations, requiring more efficient collective protective equipment. Particulate matter monitoring showed concentration in line with occupational exposure limits for inhalable dust $\left(1862 \pm 1729 \mu \mathrm{g} / \mathrm{m}^{3}\right)$ and breathable dust $\left(276 \pm 126 \mu \mathrm{g} / \mathrm{m}^{3}\right)$, however, organic particle exposure risk assessment has to be carefully reviewed. Improvements in the training program, process design, and health surveillance are desirable as major preventive tools.
\end{abstract}

Keywords: composting; bioaerosol; occupational exposure; biological risk; risk assessment

\section{Introduction}

Composting is a biotechnology for waste treatment and management. It is based on aerobic biological transformation of organic biomasses, typically the organic fraction of municipal solid waste (OFMSW) and agricultural waste, performed by a dynamic microbial community. The treatment can also be integrated with anaerobic digestion [1,2]. There are four main phases of the whole process: biomass reception and mixing; biological treatment (anaerobic digestion or/and active composting time); screening; and the final product storage. Generally, the final products are humic substances used as fertilizer in agriculture [3]. A specific regulation in terms of compost quality is imperative [4].

In the last few years, the amount of collected organic waste has risen. Biological process plants are increasing and adopting integrated anaerobic and aerobic treatment, thanks also to the reconversion of already existing plants [5]. In Europe, from 1995 to 2016, the organic matter treatment had an increase of $5.2 \%$, moving from 14 million tons to almost 40 million tons of organic waste [6]. The quantity of organic waste can occasionally be too high for the existing plant's capacity, causing waste management issues and a potential higher contamination.

Biomass manipulation contributes to bioaerosol and particulate matter emissions [7], therefore, the plants must have aspiration and air filtration systems, which are generally combined (e.g., biofilters and scrubbers). These systems are commonly used only for indoor processes, while the outdoor processes benefit from the dilution effect due to the fast dispersion, typical of an open environment. The term bioaerosol defines aerosolized particles with a biological origin like bacteria, fungi, virus, protozoa, 
algae, pollen, endotoxins, and other biologically derived particles [8,9]. Bioaerosol could be a potential risk for workers' health, especially in composting plants, where the organic matter composition is extremely heterogeneous [10]. Moreover, the complexity in microbial species and compounds is one of the main reasons for explaining the lack of occupational exposure limit values (OELs). Therefore, the interpretation of the bioaerosol exposure analysis is not clear yet [11]. Nevertheless, the microbial component of bioaerosols may represent a primary indicator of biological risk for human health and it is potentially associated with the onset of infectious diseases, allergies, and respiratory conditions such as asthma and rhinitis [12]. Generally, in composting plants, bioaerosol inhalation involves a modulation of gene expression at the respiratory level, activating an atopic inflammation [13]. Some authors have suggested an association between Actinomyces and hypersensitivity pneumonitis in composting workers [14,15]. However, nowadays, it is not possible to establish a causal link epidemiologically [16] nor a clear quantitative association between exposure and health effects [11,17-19]. Therefore, biological risk associated with bioaerosols deserves particular attention in order to identify the pathogens and opportunistic pathogens and their interaction with human organisms with the purpose of safeguarding human health. To this purpose, Basu et al. proposed a questionnaire to assess the health effects of bioaerosol exposure, which demonstrated adequate reliability when used within the analyzed composting workforce. The authors assessed the questionnaire reliability using the internal consistency approach denoted by Cronbach's alpha $(\alpha)$. They only used closed queries without specific measurements [20].

The aim of this study was to describe the Italian composting plant scenario by submitting a questionnaire to available composting facilities, associated with the Italian Composting and Biogas Consortium (CIC), in the Italian territory. Moreover, the results, obtained from the analysis of the questionnaires, are summarized in order to describe and evaluate the biological risk due to bioaerosol exposure and its management strategy by Italian composting plants.

\section{Materials and Methods}

\subsection{Questionnaire}

The Department of Public Health and Pediatrics (DPHP) of the University of Turin and the CIC created-in agreement-a questionnaire to submit to the Italian composting plants syndicated by the consortium (Figure 1). The requested data were divided into different sections containing information about the types of treated waste, plant and process description, plant location, indoor and outdoor phases, air flux management, production and management of process waters, number of workers, tasks and exposure to work environment, personal and collective protective equipment, work environment hygiene, monitoring results regarding bioaerosol and environmental particulate matter, and occupational health surveillance.

More than 80 questionnaires were sent to the facilities and 11 were filled out by plant managers and sent back (13\%, corresponding to the expected participation for this type of project in the waste treatment context). CIC anonymized the completed questionnaires and sent them to DPHP. The coverage results of the answers were quite heterogeneous due to the complexity of the questions and limited time availability declared by the plant operators. Nevertheless, the adherence to questionnaire compilation was quite good: seven plants supplied more than $75 \%$ of answers, two plant answered more than $50 \%$ and two plants answered less than $50 \%$ of the queries. Whereas the plants did not supply the requested information, integrations were requested and where the information was accessible, the plants answered with the missing data. The questionnaire is presented as Supplementary Materials Table S1. 


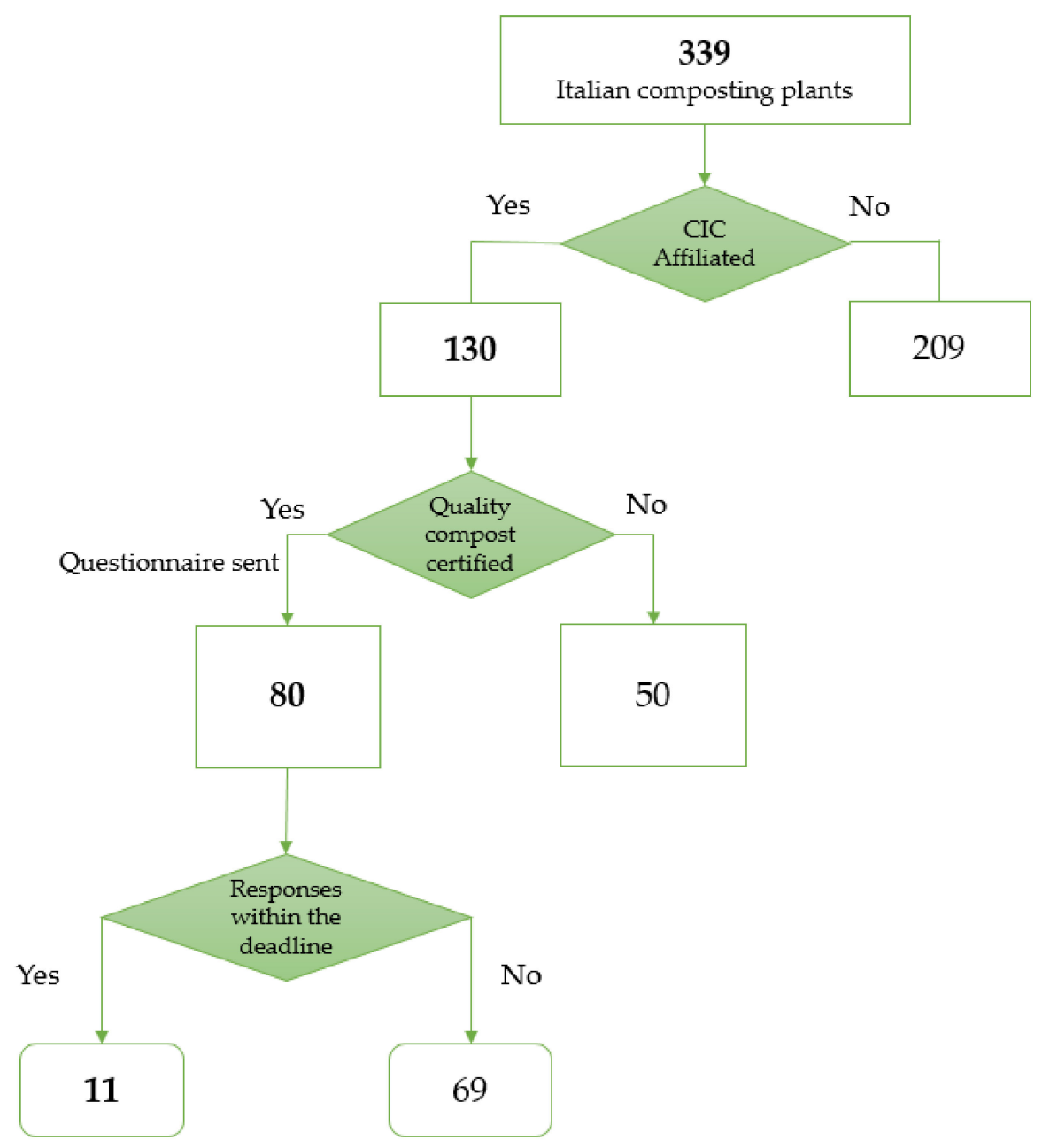

Figure 1. Flowchart of the selection process of the plants. CIC = Italian Composting and Biogas Consortium.

\subsection{Data Analysis}

The quantitative data reported are the outcome of the data elaboration; the raw data are not disclosed. The 11 plants were divided into three categories in relation to the different process or the type of waste used, and those represent an overview of the Italian composting plants:

- GWCP (1 plant): Green Waste Composting Plants use only green waste such as greenery, leaves, and ligneous waste;

- $\quad \mathrm{ADCP}$ (4 plants): Anaerobic Digestion plus Composting Plants use the green waste and organic fraction of municipal solid waste;

- $\quad$ CP (6 plants): Composting Plants use green waste and the organic fraction of municipal solid waste and only aerobic treatment is performed.

For occupational exposure analysis, the work-tasks were grouped into four macro categories following a shared evaluation between CIC and DPHP. The partition considers that a higher exposure relates to a longer time spent working outside vehicles, on the ground, directly in contact with the matrix or near the matrix [21]. Exposure profiles were finally defined as: (1) workers in vehicles for most of the time and occasionally on the ground, representing 13\% of the employees; (2) workers that spend similar times both in vehicles and on the ground, representing 54\%; (3) workers that spend most of the time on the ground as the maintainer, representing 30\%; and (4) technical employees who work in the office and also spend time in the operative department, representing $3 \%$. Volume to mass adjustments were also made to homogenize data and allow for an optimal analysis. The following 
conversions were made for waste storage: (a) $1 \mathrm{dm}^{3}=0.5 \mathrm{~kg}$ for OFMSW and (b) $1 \mathrm{dm}^{3}=0.3 \mathrm{~kg}$ for agricultural waste.

DPHP, in agreement with CIC, identified the following areas, defined in relation to the presence of bioaerosol sources: (1) reception, storage, and pre-treatment; (2) anaerobic digestion; (3) composting; (4) screening area; (5) technical space; (6) offices and changing rooms; (7) cabin; (8) outdoor area; and (9) biofilters or scrubbers.

\subsection{Microbiological Analysis}

Private labs chosen by each plant performed the analyses. The reported methods were different but referred to the UNI EN 13098 regulation [22]. A total of 81\% of the plants reported monitoring data for occupational bioaerosol concentrations, $54 \%$ of the plants reported particulate matter concentrations, and $18 \%$ of the plants reported no monitoring. Moreover, $36 \%$ of the plants also reported contact microbiological concentration data in some areas. On average, the bioaerosol monitoring reported was $1.6 \pm 1.3$ for each plant. The plant design conditioned the distance of the sampler from the source; however, the UNI EN 13098 includes the necessity of reporting such information without a numerical indication.

The biological parameters used for bioaerosol monitoring are bacteria count at $22{ }^{\circ} \mathrm{C}$, bacteria count at $30^{\circ} \mathrm{C}$, mesophilic bacteria, fungi, Gram-negative bacteria, Gram-positive bacteria, Clostridia, total coliforms, Enterococcus spp., Enterobacteria, Pseudomonadaceae, Staphylococcus spp., Aspergillus niger, Escherichia coli, Salmonella spp., and Staphylococcus aureus.

Occasionally, personal microbiological monitoring was evaluated (3/11) before and after the work shift for the following parameters: bacterial count at $30^{\circ} \mathrm{C}$, E. coli, Enterococcus spp., Clostridia, Salmonella, molds, yeasts, and Legionella spp. One plant used colony forming unit (CFU) per swab and the data was converted to $\mathrm{CFU} / \mathrm{m}^{2}$, knowing that one sample corresponds to $\mathrm{CFU} / 10 \mathrm{~cm}^{2}$ [23].

The global index of microbiological contamination (GIMC) and the index of mesophilic bacteria contamination (IMC) were calculated as reported in Dacarro et al. [24].

\subsection{Statistical Analysis}

The statistical analysis was conducted with the software IBM SPSS (IBM Corp. Armonk, NY, USA) version 25. A descriptive analysis was performed, followed by statistical analysis: (1) a log transformation to non-normally distributed data; (2) the Pearson's correlation to assess relationships between variables; (3) Mann-Whitney U test to compare means; and (4) Analysis of Variance (ANOVA) for multivariate analysis followed by a Tukey post-hoc test for multiple comparisons. The mean differences and correlations were considered significant for $p<0.05$ and highly significant for $p<0.01$.

\section{Results}

\subsection{Area Description}

The process phases were conducted in specific areas and four macro sections could be identified for all of the plants.

(1) Area of reception and mixture of inbound organic waste (as reported in point 1 of Section 2.2): Designated to receive organic waste with different types of vehicles, stock, and pre-treat biomasses. The waste bag shredding, the potential sifting, and the different types of organic waste mixture generally compose the latter phase.

(2) Area of biological treatment (as reported in points 2 and 3 of Section 2.2): Designated for composting and anaerobic digestion processes. The aerobic phase is performed in biocells or in windrows; the anaerobic digestion phase is performed in closed reactors.

(3) Area of screening and final product storage (as reported in point 4 of Section 2.2): Designated to compost screening, mainly represented by the sifting process. 
(4) Areas with different characteristics (as reported in Section 2.2 from points 5 to 9): Consist of technical space, office and changing room, cabin, outdoor area, and biofilters or scrubbers.

\subsection{Plant Design, Process, and Management Description}

The 11 investigated plants had similarities and differences, outlined by the quantity of waste in the various process areas. A wide variability was observed, especially between $\mathrm{CP}$ and $\mathrm{ADCP}$ :

- In the reception area, an average of $1920 \mathrm{~m}^{3}$ of organic waste in CPs, $7667 \mathrm{~m}^{3}$ in ADCPs, and $1000 \mathrm{~m}^{3}$ in GWCP are stocked;

- In the composting area, an average of $17,683 \mathrm{~m}^{3}$ of biomass in CPs, $5427 \mathrm{~m}^{3}$ in ADCPs, and $53,300 \mathrm{~m}^{3}$ in GWCP are stocked; and

- In the final product area, an of average $4200 \mathrm{~m}^{3}$ in CPs, $2000 \mathrm{~m}^{3}$ in ADCPs, and $7300 \mathrm{~m}^{3}$ in GWCP are stocked.

The minimum-maximum quantity of waste in tons per year is reported in Table 1 and takes into consideration all of the investigated plants.

Table 1. Minimum and maximum quantity of waste processed in tons per year (OFMSW = organic fraction of municipal solid waste).

\begin{tabular}{ccc}
\hline Waste Typology & Minimum (Tons per Year) & Maximum (Tons per Year) \\
\hline OFMSW & 19,124 & 96,000 \\
Greenery & 3680 & 34,700 \\
Others $^{1}$ & 2400 & 12,198 \\
\hline
\end{tabular}

${ }^{1}$ Others: digested sludge, materials derived from mechanical treatment of waste, and heavy dusts derived from the thermal process.

Air changes (Table 2) were actualized by all of the investigated plants, except for the GWCP. In fact, the latter only treats greenery waste in open or semi-open environments. Air mean volume in the reception was $<10,000 \mathrm{~m}^{3}$ with a wide variability and the number of air changes was around 2-3 changes per hour, except for a local, when internal volumes were higher (eight changes per hour). Air mean volume in composting is around $19,600 \mathrm{~m}^{3}$ with three to five air changes per hour. In the screening area, the air mean volume was lower, around 10,200 $\mathrm{m}^{3}$ with three air changes per hour.

Table 2. Descriptive analysis of air changes in the three main operative areas.

\begin{tabular}{lccc}
\hline \multirow{2}{*}{ Areas } & \multicolumn{2}{c}{ Volume Area $\left(\mathbf{m}^{\mathbf{3}}\right)$} & \multirow{2}{*}{ Number of Changes per Hour } \\
\cline { 2 - 3 } & Mean & Standard Deviation & \\
\hline Reception & 9686 & 5373 & $2-3$ \\
Composting & 19,601 & 10,987 & $3-5$ \\
Screening & 10,196 & 2923 & 3 \\
\hline
\end{tabular}

The GWCP conducts all operational processes such as reception, stocking, manipulation, and biomass treatment outdoors in a service area. Screening and final product storage occur outdoors, although they are protected from the rain by a canopy. Biomass is moistened during the biological process, according to necessity. Moreover, the sanitation phase is monitored via occasional temperature measurements of stacks (daily) to verify the observance of directives of $55^{\circ} \mathrm{C}$ for a minimum of three days [25].

On the other hand, CPs typically perform all the operational processes in indoor environments except, occasionally, for the reception, storage, green waste grinding, and maturation phase. Biomass is moistened during bio-oxidation and slow maturation phases; biomass stacks are oxygenized with turning stack machines when windrows occur or with forced aeration when biocells occur. 
Generally, in process areas, exhausted air is redirected to be reutilized in biological processes in biocells to insufflate the biomass, then it is sent to depuration via biological filtration. In detail, two plants exclusively used biofilters and four plants used biofilters combined with scrubbers. The sanitation phase is monitored via continuous or manual temperature measurements of stacks, in order to comply to the directives of $55^{\circ} \mathrm{C}$ for a minimum of two days to a maximum of three days [25].

Furthermore, ADCPs conduct all the operational processes in indoor settings except, occasionally, the reception and green waste storage. Biomass is moistened during digested sludge bio-oxidation and biomass stacks are oxygenized with automatized turning stack machines when maturation windrows occur or with forced aeration when biocells occur. The sanitation phase is monitored via continuous temperature measurements of the stacks, in order to comply to the directives of $55^{\circ} \mathrm{C}$ for a minimum of three days to a maximum of five days [25].

Water management is reported in Supplementary Materials Table S2 for the three plant typologies. $\mathrm{CPs}$ and ADCPs did not show substantial differences regarding the processing of waters, except for the management: ADCPs treat the leachate and process waters by sending them to third-party facilities while CPs generally recover the water and reuse it directly. GWCP only treats wheel washing, green storage, and meteoric waters that are treated by third-party facilities and recovered and unloaded in sewer and shallow waters, respectively.

\subsection{Biological Risk for Workers}

Biological risk in composting plants is typically linked to the contact frequency of organic biomasses. As reported in the questionnaires, all workers received proper biological risk training, as demanded by law [26]. The average number of workers involved in all the investigated composting plants was around 40. Workers may be in contact with inbound waste, before and after the composting process, and in the screening area. Very low frequencies were declared for waste bag shredding, feeding the shredder-mixer, weigh station, and the manipulation of organic and green waste. Low frequencies were declared for reception, cleaning and unblocking of the biomass treatment pipeline, biocell loading, screening, composting monitoring, and mechanical and electrical maintenance.

Those responsible for reception, composting, and screening, which operates both in vehicles and on the ground, can be in contact with the organic matrix at a medium or high frequency $(25-30 \%$ of workers).

Number of shifts for all the tasks and activity can vary from one to three per day, in relation to the organization of the facility. Identified exposure ways are inhalation, contact, and ingestion, and workers can also be exposed to bloodborne pathogens. Occasionally, extraordinary events can occur and emergency procedures are declared such as spills or punctures from syringes or cutting objects.

\subsection{Occupational Monitoring}

\subsubsection{Bioaerosol and Contact Microbiological Analyses}

Nine plants out of 11 performed periodical occupational bioaerosol monitoring in selected areas. In three plants, monitoring was conducted every six months; in one plant every year; in two plants every three years; and only in one plant every five years. Two plants did not declare their frequency. Regarding the collected data, the general microbial parameters investigated by the facilities are reported in Table 3. 
Table 3. Descriptive analysis of occupational bioaerosol monitoring.

\begin{tabular}{cccccc}
\hline $\begin{array}{c}\text { Parameters } \\
\text { (Log CFU/m }^{3} \text { ) }\end{array}$ & N & Minimum & Maximum & Mean & Standard Deviation \\
\hline Fungi and yeasts & 78 & 1.000 & 4.646 & 2.907 & 0.816 \\
Escherichia coli & 65 & 0.000 & 3.778 & 0.933 & 0.861 \\
Enterococcus spp. & 59 & 0.301 & 4.288 & 1.550 & 1.081 \\
Bacterial count at $30^{\circ} \mathrm{C}$ & 51 & 1.699 & 4.875 & 3.490 & 0.645 \\
Mesophilic bacterial count & 34 & 2.041 & 3.778 & 2.958 & 0.504 \\
Bacterial count at $22^{\circ} \mathrm{C}$ & 32 & 2.114 & 4.410 & 3.270 & 0.500 \\
Staphylococcus spp. & 28 & 0.000 & 2.114 & 0.968 & 0.531 \\
Pseudomonadaceae & 27 & 0.000 & 1.799 & 0.935 & 0.410 \\
Staphylococcus aureus & 26 & 0.301 & 1.643 & 0.790 & 0.396 \\
Total Coliforms & 20 & 0.000 & 2.575 & 0.732 & 0.797 \\
Clostridia & 16 & 0.000 & 2.574 & 1.368 & 1.113 \\
Salmonella spp. & 16 & 0.000 & 2.574 & 1.067 & 1.116 \\
Legionella spp. & 14 & 0.000 & 0.000 & 0.000 & 0.000 \\
Total bacteria & 12 & 2.000 & 3.322 & 2.734 & 0.427 \\
Molds & 8 & 1.574 & 3.477 & 2.702 & 0.687 \\
Enterobacteria & 8 & 0.602 & 2.628 & 1.215 & 0.851 \\
Gram-negative & 6 & 1.477 & 3.176 & 2.432 & 0.656 \\
Gram-positive & 6 & 2.000 & 3.279 & 2.775 & 0.571 \\
Actinomyces & 1 & 2.690 & 2.690 & 2.690 & - \\
GIMC & - & 2.458 & 4.897 & 3.996 & - \\
IMC & - & -0.07 & -0.638 & -0.366 & - \\
\hline
\end{tabular}

Note: $\mathrm{CFU}=$ colony forming unit; $\mathrm{N}$ = number of measurements. GIMC = global index of microbial contamination; IMC = mesophilic bacteria contamination.

Fungi and yeasts were the most analyzed biological parameters, others were E. coli, Enterococcus spp., and bacterial counts at $22^{\circ} \mathrm{C}$ and at $30^{\circ} \mathrm{C}$. The least studied parameters were Enterobacteria, Gram-negative and Gram-positive bacteria, and Actinomyces. Two facilities also tested Aspergillus niger positivity (data not showed). Two rising interesting parameters were Legionella spp., which was investigated by only two facilities, and Actinomyces, which was analyzed by one plant.

GIMC showed an average high contamination of $>10,000 \mathrm{CFU} / \mathrm{m}^{3}$ for the investigated plants and a low $\operatorname{IMC}(<3)$.

Moreover, a descriptive analysis was performed between the bioaerosol concentration and the type of treated biomass: mixed (greenery and OFMSW) and greenery (Table 4). Only the greenery plant investigated a few parameters: bacteria count at $22{ }^{\circ} \mathrm{C}$, mesophilic count, fungi and yeasts, Staphylococcus aureus, Enterococcus spp., Escherichia coli, and total coliforms. Statistically significant differences for comparable parameters included Enterococcus spp., Escherichia coli, Staphylococcus aureus $(p<0.01)$, and total coliforms $(p<0.05)$.

Table 4. Descriptive analysis of statistically significant biological parameters in relation to treated waste typology. Mixed $=10$ plants, greenery $=1$ plant. $\mathrm{CFU}=$ colony forming unit.

\begin{tabular}{cccccc}
\hline \multirow{2}{*}{$\begin{array}{c}\text { Parameters }(\text { Log } \\
\text { CFU } / \mathbf{m}^{3} \text { ) }\end{array}$} & Mean & $\begin{array}{c}\text { Standard } \\
\text { Deviation }\end{array}$ & Mean & $\begin{array}{c}\text { Standard } \\
\text { Deviation }\end{array}$ & \\
\cline { 2 - 5 } & 1.007 & 0.262 & 0.301 & 0.000 & $<0.01$ \\
\hline Staphylococcus aureus & 1.865 & 1.076 & 0.704 & 0.485 & $<0.01$ \\
\hline Enterococcus spp. & 1.140 & 0.901 & 0.301 & 0.000 & $<0.01$ \\
\hline Escherichia coli & 1.020 & 0.934 & 0.301 & 0.000 & $<0.05$ \\
\hline Total coliforms & & & & & \\
\hline
\end{tabular}

Moreover, a descriptive analysis was performed between the bioaerosol concentration and process type divided into only aerobic and aerobic plus anaerobic digestion. Analysis showed a higher concentration in CPs with respect to ADCPs. For four parameters, such differences were statistically significant: bacteria count at $22{ }^{\circ} \mathrm{C}\left(3.936\right.$ vs. $\left.3.160 \mathrm{Log} \mathrm{CFU} / \mathrm{m}^{3} ; p<0.05\right)$; fungi and yeasts (3.366 vs. 
2.631 Log CFU $/ \mathrm{m}^{3} ; p<0.01$ ); Enterococcus spp. (2.801 vs. $1.310 \mathrm{Log}$ CFU/m3; $\left.p<0.01\right)$; and E. coli (1.516 vs. $\left.0.833 \mathrm{Log} \mathrm{CFU} / \mathrm{m}^{3} ; p<0.05\right)$.

Therefore, the following analysis focused on the differences between the distinctive plant designs: biocells or windrows and service area. In Table 5, microbiological parameters that significantly varied are shown. In detail, fungi and Staphylococcus spp. resulted in higher biocell plants with respect to windrows plants $(p<0.01)$.

Table 5. Descriptive analysis of investigated parameters in relation to biocells, windrows, and service area application. CFU = colony forming unit.

\begin{tabular}{|c|c|c|c|c|c|c|}
\hline \multirow{2}{*}{$\begin{array}{c}\text { Parameters } \\
\left(\log \text { CFU/m }{ }^{3}\right)\end{array}$} & \multicolumn{2}{|c|}{ Biocells } & \multicolumn{2}{|c|}{ Windrows } & \multicolumn{2}{|c|}{ Service Area } \\
\hline & Mean & $\begin{array}{c}\text { Standard } \\
\text { Deviation }\end{array}$ & Mean & $\begin{array}{l}\text { Standard } \\
\text { Deviation }\end{array}$ & Mean & $\begin{array}{l}\text { Standard } \\
\text { Deviation }\end{array}$ \\
\hline Fungi and yeasts & 3.228 & 0.591 & 2.457 & 1.068 & 2.967 & 0.195 \\
\hline Staphylococcus spp. & 1.206 & 0.519 & 0.651 & 0.365 & . & . \\
\hline Staphylococcus aureus & 1.000 & - & 0.000 & 1.017 & 0.408 & 0.301 \\
\hline Enterococcus spp. & 2.137 & - & 1.027 & 1.238 & 0.943 & 0.704 \\
\hline Escherichia coli & 1.368 & - & 0.907 & 0.506 & 0.502 & 0.301 \\
\hline Total coliforms & 1.547 & - & 1.017 & 0.492 & 0.468 & 0.301 \\
\hline
\end{tabular}

Moreover, an analysis of the bioaerosol concentration was performed in relation to the ADCPs' plant design, which can be either biocells or windrows. The statistically significant differences were bacterial count at $22{ }^{\circ} \mathrm{C}(3.450$ vs. $2.838 ; p<0.01)$, fungi and yeasts $(2.994$ vs. $2.457 ; p<0.01)$, Staphylococcus spp. (1.401 vs. $0.651 ; p<0.01)$, and E. coli $(1.136$ vs. $0.506 ; p<0.01)$ with a higher concentration for the biocell design.

The same analysis was conducted for CPs using biocells or windrows. The data only showed a significant difference for bacterial count at $30^{\circ} \mathrm{C}$, being higher in windrow plants (4.086 vs. 3.501; $p<0.05)$.

In order to outline different microbial concentrations in the various areas, an analysis of bioaerosol levels in the nine areas was conducted. Statistically significant differences were observable for Enterococcus spp. and E. coli. Enterococcus spp. concentrations were higher in the reception with respect to technical spaces, offices, and changing rooms $(p<0.05)$; in composting with respect to technical spaces, offices, changing rooms, and cabins $(p<0.01)$; and in biofilters and scrubbers with respect to technical spaces and cabins $(p<0.05)$. On the other hand, E. coli concentrations were higher in composting with respect to offices and changing rooms $(p<0.05)$; in biofilters and scrubbers with respect to the reception, offices, and changing rooms, cabins, technical spaces, and outdoor areas $(p<0.05)$. The highest bioaerosol concentrations of E. coli and Enterococcus spp. were reported in the biofilters and scrubbers ( $2500 \mathrm{CFU} / \mathrm{m}^{3}$ and $19,400 \mathrm{CFU} / \mathrm{m}^{3}$, respectively). Generally, the results of the concentrations were scattered and it was possible to observe that bacterial count at $22{ }^{\circ} \mathrm{C}$ correlated with bacterial count at $30^{\circ} \mathrm{C}$ (Pearson's rho $=0.826 ; p<0.01$ ), Gram-positive bacteria (Pearson's rho = 0.997; $p<0.05$ ), and fungi and yeasts (Pearson's rho $=0.548 ; p<0.01$ ). Moreover, the fungi and yeast counts correlated with Clostridia (Pearson's rho $=0.674 ; p<0.01$ ).

Finally, four plants also performed contact plate microbiological monitoring in the reception, digestion, technical spaces, offices, changing rooms, and cabins. Higher bioaerosol concentration was detected for bacterial count at $22{ }^{\circ} \mathrm{C}$ in technical spaces $\left(2.51 \pm 0.11 \mathrm{Log} \mathrm{CFU} / \mathrm{m}^{3}\right)$; bacterial count at $30{ }^{\circ} \mathrm{C}\left(2.66 \pm 0.96 \mathrm{Log} \mathrm{CFU} / \mathrm{m}^{3}\right)$ in the reception; for mesophilic count $\left(2.59 \pm 0.54 \mathrm{Log} \mathrm{CFU} / \mathrm{m}^{3}\right)$ in cabins; and fungi and yeasts $\left(2.03 \pm 0.22 \mathrm{Log} \mathrm{CFU} / \mathrm{m}^{3}\right)$ in the reception. No statistically significant differences were detected.

\subsubsection{Personal Microbiological Analysis}

Before the work shift, the average concentration was $429.50 \pm 1123.74 \mathrm{CFU} / \mathrm{m}^{2}$ for bacterial count at $30^{\circ} \mathrm{C}$ and $1750 \pm 1767.77 \mathrm{CFU} / \mathrm{m}^{2}$ for fungi and molds. After the work shift, the average concentration 
was $23.02 \pm 36.53 \mathrm{CFU} / \mathrm{m}^{2}$ for bacterial count at $30{ }^{\circ} \mathrm{C}$ with a maximum of $33 \mathrm{CFU} / \mathrm{m}^{2}$ in the reception. Moreover, after the work shift, $3300 \mathrm{CFU} / \mathrm{m}^{2}$ was registered for molds in one plant. For the remaining parameters, the concentration result was $<10 \mathrm{CFU} / \mathrm{m}^{2}$.

\subsubsection{Particulate Matter Monitoring}

Questionnaire data elaboration showed that six plants out of 11 performed particulate matter monitoring. No plant conducted airborne endotoxin analysis. In the ADCP, the inhalable and breathable dust were low and acceptable with concentrations below 5.32 and $0.35 \mathrm{mg} / \mathrm{m}^{3}$, respectively (Table 6).

Table 6. Inhalable and breathable dust monitoring at the ADCP facilities. ADCP = anaerobic digestion plus composting plants.

\begin{tabular}{ccccc}
\hline ADCP Facilities & Minimum & Maximum & Mean & Standard Deviation \\
\hline $\begin{array}{c}\text { Inhalable dust } \\
\left(\mathrm{mg} / \mathrm{m}^{3}\right)\end{array}$ & 0.38 & 5.32 & 1.77 & 1.69 \\
$\begin{array}{c}\text { Breathable dust } \\
\left(\mathrm{mg} / \mathrm{m}^{3}\right)\end{array}$ & 0.22 & 0.35 & 0.28 & 0.12 \\
\hline
\end{tabular}

In Table 7, the concentrations detected in the CPs are reported and the environmental $\mathrm{PM}_{10}$ reached a maximum of $7.80 \mathrm{mg} / \mathrm{m}^{3}$ in the composting area.

Table 7. Particulate matter and inhalable dust monitoring for the $\mathrm{CP}$ facilities. $\mathrm{CP}=$ composting plants.

\begin{tabular}{lcccc}
\hline \multicolumn{1}{c}{ CP Facilities } & Minimum & Maximum & Mean & Standard Deviation \\
\hline Inhalable dust $\left(\mathrm{mg} / \mathrm{m}^{3}\right)$ & 6.60 & 6.60 & 6.60 & - \\
Environmental $\mathrm{PM}_{10}\left(\mathrm{mg} / \mathrm{m}^{3}\right)$ & 0.83 & 7.80 & 3.19 & 2.34 \\
Environmental $\mathrm{PM}_{2.5}\left(\mathrm{mg} / \mathrm{m}^{3}\right)$ & 0.25 & 0.87 & 0.57 & 0.26 \\
Environmental $\mathrm{PM}_{2.5} / \mathrm{PM}_{10}$ & 0.12 & 0.29 & 0.19 & 0.08 \\
Personal $\mathrm{PM}_{10}\left(\mathrm{mg} / \mathrm{m}^{3}\right)$ & 0.65 & 2.11 & 1.20 & 0.79 \\
Personal $\mathrm{PM}_{2.5}\left(\mathrm{mg}^{3} / \mathrm{m}^{3}\right)$ & 0.04 & 0.05 & 0.04 & 0.005 \\
Personal $\mathrm{PM}_{2.5} / \mathrm{PM}_{10}$ & 0.02 & 0.06 & 0.04 & 0.02 \\
\hline
\end{tabular}

\subsection{Plants Location}

Plants are generally located in areas designated for agriculture or near small industrial facilities. In adjacent areas $(<0.5 \mathrm{~km})$, the presence of wastewater treatment plants is often reported and at further distances $(>0.5 \mathrm{~km}$ and $<1 \mathrm{~km})$, agricultural businesses, livestock, and woods are located. Moreover, nearby some plants, other facilities such as farming or wastewater treatment plants are located, which could represent both a source of bioaerosol and a barrier to the dispersion of emissions. Plants that have green areas such as woods and agricultural fields within $500 \mathrm{~m}$ revealed higher bioaerosol concentrations; in detail, the difference was statistically significant for the bacterial count at $30{ }^{\circ} \mathrm{C}$ $\left(11,452.15 \pm 19,058.34\right.$ vs. $\left.2386.50 \pm 3020.45 \mathrm{CFU} / \mathrm{m}^{3}\right)$; fungi and yeasts $(5478.79 \pm 11,496$ vs. $1494.45 \pm$ $\left.2070.01 \mathrm{CFU} / \mathrm{m}^{3}\right)$, and Staphylococcus aureus $\left(15.25 \pm 14.41 \mathrm{vs.} 6.44 \pm 4.09 \mathrm{CFU} / \mathrm{m}^{3}\right)(p<0.05)$. Regarding the plants confining with industrial facilities (eight out of 11), a higher bioaerosol concentration was observed for bacterial count at $30^{\circ} \mathrm{C}\left(10,549.55 \pm 16,877.5\right.$ vs. $\left.2887.98 \pm 6712.85 \mathrm{CFU} / \mathrm{m}^{3}\right)$; Escherichia coli $\left(127.57 \pm 434.08\right.$ vs. $\left.5.23 \pm 11.63 \mathrm{CFU} / \mathrm{m}^{3}\right)$; and total coliforms (55 \pm 44.64 vs. $\left.2 \pm 0 \mathrm{CFU} / \mathrm{m}^{3}\right)(p<0.05)$.

\subsection{Work Environment and Personal Hygiene}

As disclosed in the questionnaires, the vehicle cabins and the changing rooms were regularly sanitized. Changing rooms offer clothes separation between dirty and clean and the dirty clothes are entrusted to industrial or their own laundries. All workers must take a shower at the end of every shift or after operating in potentially contaminated environments. 
All plants have adopted disinfestation and rodent control procedures, but not every plant conducted a periodic control for insects and other vectors, birds included. Internal or external specialized personnel perform these control procedures.

\subsection{Personal and Collective Protective Equipment}

Plants employed collective protective equipment (CPE) that can intervene more or less efficiently on the contaminating source before a single worker is involved, or that tend to reduce the impact of hazardous substances on the workers in a specific environment. The CPE adopted by the investigated plants were as follows: waste partitioning, aspiration or localized aspiration, air change, cabin and control room filters, dust exhaustion, biofilters, sleeve filters, and general cleaning.

Moreover, to reduce biological risk, personal protective equipment (PPE) was employed and designated to be worn by the workers with the purpose of protecting them against one or more risks present in the working environment that can threaten the worker's safety or health. The PPEs adopted by the composting facilities were homogenous and the different tasks did not require great discrepancies. Proper personnel education for the third category of PPEs-complex design equipment designated to safeguard death risks or serious injuries-was declared by $54 \%$ of the plants, but the four remaining plants could not be classified as not educated. For task 1, the PPEs were as follows: gloves, coverall, goggles, filtering mask filtering face piece 1 (FFP1), FFP2, and FFP3, safety shoes, ear defenders, and helmet. For tasks 2 and 3, the PPEs were as follows: gloves, coverall, goggles, filtering mask FFP1, FFP2, and FFP3, safety shoes, ear defenders, helmet, breathing apparatus, escape hoods, and ABEK masks with combined filters against multiple hazards $\left(\mathrm{A}=\right.$ High-boiling $\left(>65^{\circ} \mathrm{C}\right)$ organic compounds, $\mathrm{B}=$ Inorganic gases, $\mathrm{E}=$ Sulfur dioxide and hydrogen chloride, $\mathrm{K}=$ Ammonia and amines). Non-disposable PPEs were generally inspected before the use or weekly, and were revised according to the instruction manual and periodically sanitized.

\subsection{Occupational Health Surveillance}

The analysis of the questionnaire data showed that medical check-ups were set every year and imposed some variable health checks. All occupational medicine checks established blood and urine chemistry tests (azotemia, glycemic index, creatinine, total protein, Complete Blood Count (CBC), transaminases, Hepatitis B Virus (HBV), Hepatitis A Virus (HAV) and Hepatitis C Virus (HCV) antibodies detection). Another test performed was the spirometry exam to evaluate a potential pulmonary function decrease every one to three years. Other performed exams were an eye examination (every one to two years), vertebral column functional evaluation, coproculture, and parasitological examination. No forced expiratory volume in 1 second (FEV1) and forced vital capacity (FCV) were reported by the facilities, although a decrease in respiratory parameters could be associated with exposure to organic matrices, as reported in the literature [27-30].

Facilities offer directly vaccination for tetanus (45\% of the facilities), hepatitis A (36\%), typhus $(0.9 \%)$, and flu $(0.9 \%)$, while other vaccinations are only suggested ( $27 \%$ of the facilities). Among these, there were also vaccinations against hepatitis B. As declared by the facilities, no case of injury or occupational illness was related to biological risk throughout the company history. A few specific pathogen risk assessments in relation to work tasks were reported. Two facilities indicated HIV, HBV, and $\mathrm{HCV}$ as biological agents that can represent a low risk for workers operating in the composting area, while the risk of contracting tetanus is medium for workers on vehicles. Furthermore, the risk of contracting hepatitis A, which is transmissible via the fecal-oral route, was considered by most of the plants to be negligible for workers in vehicles in the composting area.

\section{Discussion}

In the last few decades, biological risk for composting workers has been of great interest to researchers, however, the risk assessment in a real situation of a full-scale plant is not complete. Due to the high heterogeneity of the processes and the sampling methods, the conducted analysis is only 
descriptive, with the aim to outline a general view of bioaerosol presence and characterization as well as supplying an objective description of the microbial concentration in order to improve risk management.

\subsection{Bioaerosol Influencing Factors}

Regarding plant locations, the facilities were mostly established near areas destined for agricultural use, small industrial plants, or woodlands. These settings are characterized by a background level of bioaerosol, influenced by both natural and anthropic factors, which is often not considered in the bioaerosol analysis. The presence of green barriers has a particular influence on fungal levels, while the presence of livestock activity or a wastewater treatment plant influences the bacterial concentrations [31,32].

The screening and biological treatment areas were characterized per se by a bioaerosol diffusion that could be inhaled by the workers.

The majority of the investigated plants were CPs that treated OFMSW and greenery waste. OFMSW represents the most processed type of waste by these facilities, with a range between 19,000 and 96,000 tons per year. The organic fraction quantity is increasing every year and represents an issue for waste management. Some Italian regions are exporting high quantities of organic and general urban waste due to the high demand and low number of facilities for waste disposal [5]. This entails a higher associated cost as well as an overload of the existing plants.

\subsection{Analysis of the Management Practices}

To date, there is still a lack of implementation of standardized procedures for microorganism characterization in different environments, even if technical procedures and guidelines are available [22,33]. Moreover, since the human response to bioaerosols can vary, accepted and shared international threshold limit values or occupational exposure limits for biological agents are still missing. Notwithstanding, some countries have proposed acceptable limits. For example, Germany set acceptable concentrations of $10^{4} \mathrm{CFU} / \mathrm{m}^{3}$ of fungi (including Aspergillus spp.) in workplaces [34], and Russia proposed limits for fungi and Actinomycetes ranging from $10^{3}$ to $10^{4} \mathrm{cells} / \mathrm{m}^{3}$ [35]. Moreover,

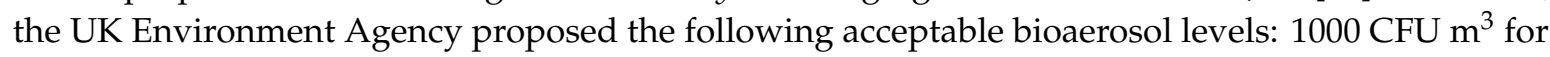
total bacteria and $500 \mathrm{CFU} / \mathrm{m}^{3}$ for Aspergillus fumigatus at $250 \mathrm{~m}$ from the facility [36]. In Poland, the Polish Committee for the Highest Permissible Concentrations and Intensities of Noxious Agents in the workplace proposed limits of $100,000 \mathrm{CFU} / \mathrm{m}^{3}$ for mesophilic bacteria and $50,000 \mathrm{CFU} / \mathrm{m}^{3}$ for fungi count [37].

Microbiological analysis showed that fungi and yeasts were the most analyzed parameters and two plants also tested for Aspergillus niger, a mold that together with A. fumigatus is associated with the onset of pulmonary infections [38]. The positivity was detected in an outdoor area of a $\mathrm{CP}$ and in a vehicle cabin of a GWCP. Aspergillus spp. can potentially cause a broad spectrum of respiratory illnesses, allergic bronchopulmonary aspergillosis (ABPA) and allergic aspergillus sinusitis, aspergilloma and invasive diseases including invasive aspergillosis, airway invasive aspergillosis, and chronic necrotizing pulmonary aspergillosis $[39,40]$. Poole et al. described two cases of allergic bronchopulmonary aspergillosis in a team of 28 garden waste (compost) collectors and suggested a pre-employment screening and regular health surveillance to confirm or exclude any professional illness [41]. Fungi concentrations results were consistent with the reported data in the literature [13,42] but higher than the proposed limits.

Moreover, a high concentration of E. coli and Enterococcus spp. in mixed waste suggests that the bioaerosol produced from heterogeneous sources including OFMSW, implicated a higher presence of enteric microorganisms [43,44]. The registered concentrations were consistent with the literature [43].

The anaerobic and aerobic treatment significantly reduced the microbial concentrations for bacterial count at $22{ }^{\circ} \mathrm{C}$, fungi and yeasts, Enterococcus spp., and E. coli. Data showed that the application of biocells was associated with high bioaerosol concentrations, could be due to the high amount of 
residual waste moved by the vehicles that carry the biomass, unlike the windrow application that uses conveyors.

Limited to the collected data from the questionnaires, ADCPs that utilized windrows had a lower bioaerosol concentration with respect to biocell systems. This result seems to be unusual and probably conditioned by the time of opening and closing of the cells, however, it has to be supported by an analysis with more facilities and with the evaluation of both the plants' peculiarities and the presence of a previous step of anaerobic digestion. It has to be outlined that anaerobic digestion could be a precious biological phase that preliminarily treats the organic biomass with respect to employment of only the aerobic treatment.

CPs that utilize biocells or windrows did not show statistically significant differences for bacterial count at $30^{\circ} \mathrm{C}$; this missing difference could be due to the lack of a previous step of an anaerobic phase. There were also differences in bioaerosol concentration in the different areas and as expected, the most contaminated areas were the reception, biofilters and scrubbers, and composting. The high E. coli and Enterococcus spp. concentrations in the biofilters and scrubbers was probably due to a significant microbial growth, which was presumably caused by poor management of the area. Generally, the levels decreased in the area from the beginning to the end of the composting process. This may perhaps be due to the biological treatment that degrades and modifies the organic matter and consequently the aerosolized microbial community.

The particulate matter monitoring showed high levels, but were in line with the occupational exposure limits for particles not otherwise classified (PNOC) $\left(3 \mathrm{mg} / \mathrm{m}^{3}\right.$ for the breathable fraction and $10 \mathrm{mg} / \mathrm{m}^{3}$ for the inhalable fraction) [8]. However, a characterization of such particles is desirable as it increases the knowledge of the human health effects of primary biological particles as well as to exclude or estimate the proportion of a particular dust such as wood, for which more rigorous limits are demanded [8]. In CPs, the $\mathrm{PM}_{10}$ levels were lower than both the European Union $\left(50 \mu \mathrm{g} / \mathrm{m}^{3}\right.$ day mean) and World Health Organization (WHO) $\left(20 \mu \mathrm{g} / \mathrm{m}^{3}\right.$ year mean) Environmental Air Quality Guideline values; $\mathrm{PM}_{2.5}$ levels were lower than the WHO limits $\left(10 \mu \mathrm{g} / \mathrm{m}^{3}\right.$ year mean) [45].

No plant conducted airborne endotoxins analysis, despite it being a significant component of bioaerosols in composting facilities, and some national regulations include parameters such as a reference for bioaerosol concentration [34]. Endotoxins are related to the onset of respiratory symptoms and a continuous occupational exposure at elevated concentrations $\left(>200\right.$ endotoxin unit per $\left.\mathrm{m}^{3}\right)$ is linked to the onset of chronic obstructive disease of the respiratory system [46].

Personal microbial monitoring showed high concentrations of molds in one plant after the work shift, but the facility did not declare any criticality during the process. A reduction in the personal microbial load after the work shift is undoubtedly desirable. Madsen et al. intervened in the form of a combination of attention to and knowledge of hygiene and adherence to a few basic guidelines with the aim of reducing the exposure to airborne microorganisms and improving hand and truck cabin hygiene. The measures applied by the waste collection workers resulted in a reduction in bacterial and fungal concentration, but only slightly in the reduction in exposure to airborne bioaerosols. Basic procedures such as keeping the cabins clean and tidy, using hand sanitizer multiple times a day, and using clean gloves every day could help with personal microbial reduction [47].

Workers can be in contact with the organic biomass in different areas of the facility, but frequency differs in relation to the task. Therefore, a higher use of vehicles reduces the contact with the organic waste, thus lowering the risk [21]. The first weapon against bioaerosol diffusion is the collective protective equipment (CPE) used by all plants, except for GWCP, which processes the organic waste outdoor. CPEs contain the bioaerosol dispersion as much as possible, especially in some areas that are more prone to bioaerosol emissions such as screening and biological treatment. The individual protective equipment represents the last chance to contain bioaerosol diffusion since it is desirable to have functioning and efficient CPE first. Indeed, the employment of proper risk containment systems (e.g., cabins with filters) is useful in the reduction of the risk to acceptable levels [15]. 
It has been suggested that exhaustion systems such as local aspiration and water nebulization are used to limit the diffusion of dust, despite the latter introducing a risk factor for the inhalation of Legionella spp., which is ubiquitous in water. In the literature, it is reported that compost can represent a Legionella spp. reservoir, but a minimal infective dose is still unknown [48,49]. Moreover, all the plants conducted disinfestation and rodent control procedures, but only a few adopted measures for controlling insects and other vectors. It is well known that insects can be vectors of diseases such as Lyme disease and Shigellosis [50,51], therefore facilities need to implement specific measures for these issues.

Regarding occupational health surveillance, a competent physician is generally an external consultant. An occupational physician collaborates with the risk evaluation and suggests appropriate preventive measures such as HVB, HVA, and tetanus vaccination. Nevertheless, the vaccinations were proposed only in a few plants. Even if vaccination is a useful preventive tool, it is not the most exhaustive for the prevention and control of biological risk. In a cross-sectional study, Bünger et al. tested workers for specific antibodies for molds and Actinomycetes as immunological markers of bioaerosol exposure. They concluded that a high exposure to bioaerosols by compost workers was significantly associated with a higher concentration of precise antibodies against molds and Actinomycetes as well as a higher frequency of health complaints and diseases [52]. Therefore, periodical serological screening investigations are desirable to investigate antibodies for specific microorganisms and to track the actual exposure of the workers to biological risks, with respect to a control population even without symptoms. Moreover, coproculture and parasitological examination could also exclude transmission in the workplace and secondary cases outside the facilities.

\subsection{Study Limitations}

The CIC sent around 80 questionnaires and only 13\% (11) of the facilities completed it, resulting in $3.2 \%$ of Italian composting plants. This appears to be quite a good result, also considering that this has been the only survey conducted in Italy on composting plants. In fact, it would probably not be possible to obtain data without the collaboration of the CIC. On the other hand, the selected plants do not reflect the complete complexity of the reality of Italian composting. Moreover, the participation was influenced primarily by the plant type. The answers were mainly obtained by plants with certain characteristics such as larger facilities and expansion goals in the Italian territory. Waste treatment managers are generally hesitant to participate in investigations as they are worried about the surrounding communities and their perception regarding human health risks and environmental quality.

Some investigated facilities did not supply complete satisfactory replies to the queries. Furthermore, the plants could have selected the data to show in the questionnaire, dismissing perhaps other data, resulting in an underestimation of the declared concentrations; on the other hand, the reported concentrations were already high.

The produced data may vary due to sampling phases, different seasons, and sampling variability. There are currently no guidelines on the microbiological parameters to evaluate for a biological risk assessment, but the samplings were conducted using standard procedures.

\section{Conclusions}

The occupational risk associated with bioaerosol exposure is not negligible around the world nor in Italy. The majority of plants have rapidly changed, which has also changed its management in relation to the expansion of the economic interest in such fields of activity. This survey included only voluntary participatory plants and it can be seen as an evaluation of the best managed plants in Italy. The topic is relevant in relation to both the increase in the treated waste and the exposed workers. The concentration levels were higher in all of the process phases, but particularly in the reception and storage area and in screening. These values were above the proposed exposure limits by some international organizations [34]. A significant difference could be observed mainly with respect to the nature of the treated waste and the treatment process (anaerobic and/or aerobic). 
The microbiological parameters can be simplified to total bacterial count at $30^{\circ} \mathrm{C}$, also considering the thermophilic conditions of the majority of the process; fungi and yeast; Enterococcus spp.; and E. coli. Such parameters could be useful bioaerosol bio-indicators of contamination derived from human and animal feces, providing a warning for possible health hazards. Moreover, Clostridia and Bacillus can be useful for their resistance ability.

There are no clear guidelines for occupational surveillance activities; therefore, the homogenization, for example, of medical examination frequency among the plants, is due.

Finally, better risk assessment and management will be reachable only through an improved characterization of both bioaerosol and organic particulate matter.

Supplementary Materials: The following are available online at http://www.mdpi.com/2073-4433/11/4/398/s1, Table S1: Questionnaire submitted to the Italian composting plants; Table S2: Water management including collecting system, recovery system, and management for the three types of plants.

Author Contributions: Conceptualization, D.T.; Methodology, D.T.; Software, D.T.; Validation, D.T.; Questionnaire analysis, D.T.; Formal analysis, D.T.; Investigation, D.T. and E.A.; Resources, D.T.; Data curation, D.T.; Writing-Original draft preparation, E.A.; Writing-Review and editing, D.T. and E.A.; Project administration, D.T.; Supervision, D.T.; Funding acquisition, D.T. All authors have read and agreed to the published version of the manuscript.

Funding: This research was funded by the CIC, grant number: TRADCTRIC_1701, and the University of Torino.

Acknowledgments: Special acknowledgements are due to the involved plants for their participation in the project.

Conflicts of Interest: The authors declare no conflict of interest.

\section{References}

1. Ishii, K.; Fukui, M.; Takii, S. Microbial succession during a composting process as evaluated by denaturing gradient gel electrophoresis analysis. J. Appl. Microbiol. 2000, 89, 768-777. [CrossRef]

2. Hansgate, A.M.; Schloss, P.D.; Hay, A.G.; Walker, L.P. Molecular characterization of fungal community dynamics in the initial stages of composting. FEMS Microbiol. Ecol. 2005, 51, 209-214. [CrossRef]

3. Wéry, N. Bioaerosols from composting facilities-A review. Front. Cell. Infect. Microbiol. 2014, 4, 42.

4. Commission of the European Communities. GREEN PAPER-On the Management of Bio-waste in the European Union-COM(2008) 811 Final; Publications Office of the European Union: Luxembourg, 2008.

5. ISPRA. Municipal Waste Report-Edition 2019; Vol.313; Istituto Superiore per la Protezione e la Ricerca Ambientale: Rome, Italy, 2018; ISBN 978-88-448-0971-3.

6. Eurostat Municipal Waste Statistics. Available online: http://ec.europa.eu/eurostat/statistics-explained/ (accessed on 4 December 2019).

7. Douglas, P.; Robertson, S.; Gay, R.; Hansell, A.L.; Gant, T.W. A systematic review of the public health risks of bioaerosols from intensive farming. Int. J. Hyg. Environ. Health 2018, 221, 134-173. [CrossRef]

8. ACGIH. TLVs and BEIs, Based on the Documentation of the Threshold Limit Values for Chemical Substances and Physical Agents and Biological Exposure Indices.; American Conference of Governmental Indutrial Hygienists: Cincinnati, OH, USA, 2006; ISBN 978-1882417629.

9. Kim, K.; Kabir, E.; Jahan, S.A. Airborne bioaerosols and their impact on human health. J. Environ. Sci. 2018, 67, 23-35. [CrossRef]

10. Ellwood, P.; Bradbrook, S.; Reynolds, J.; Duckworth, M. Green Jobs, New Risks? New and Emerging Risks to Occupational Safety and Health in the Electricity Sector; Pubblications Office of the European Union: Luxembourg, 2014.

11. Duquenne, P. On the identification of culturable microorganisms for the assessment of biodiversity in bioaerosols. Ann. Work Expo. Health 2018, 62, 139-146. [CrossRef]

12. Pearson, C.; Littlewood, E.; Douglas, P.; Robertson, S.; Gant, T.W.; Hansell, A.L. Exposures and Health Outcomes in Relation to Bioaerosol Emissions From Composting Facilities: A Systematic Review of Occupational and Community Studies. J. Toxicol. Environ. Health Part B 2015, 18, 43-69. [CrossRef]

13. Chang, M.W.; Lee, C.R.; Hung, H.F.; Teng, K.S.; Huang, H.; Chuang, C.Y. Bioaerosols from a food waste composting plant affect human airway epithelial cell remodeling genes. Int. J. Environ. Res. Public Health 2014, 11, 337-354. [CrossRef] 
14. Bünger, J.; Schappler-Scheele, B.; Hilgers, R.; Hallier, E. A 5-year follow-up study on respiratory disorders and lung function in workers exposed to organic dust from composting plants. Int. Arch. Occup. Environ. Health 2007, 80, 306-312. [CrossRef]

15. Schlosser, O.; Huyard, A.; Cartnick, K.; Yañez, A.; Catalán, V.; Do Quang, Z. Bioaerosol in Composting Facilities: Occupational Health Risk Assessment. Water Environ. Res. 2009, 81, 866-877. [CrossRef]

16. Stang, A.; Poole, C.; Kuss, O. The ongoing tyranny of statistical significance testing in biomedical research. Eur. J. Epidemiol. 2010, 25, 225-230. [CrossRef] [PubMed]

17. Liebers, V.; van Kampen, V.; Bünger, J.; Düser, M.; Stubel, H.; Brüning, T.; Raulf-Heimsoth, M. Assessment of Airborne Exposure to Endotoxin and Pyrogenic Active Dust Using Electrostatic Dustfall Collectors (EDCs). J. Toxicol. Environ. Health Part A 2012, 75, 501-507. [CrossRef]

18. Douglas, P.; Bakolis, I.; Fecht, D.; Pearson, C.; Leal Sanchez, M.; Kinnersley, R.; de Hoogh, K.; Hansell, A.L. Respiratory hospital admission risk near large composting facilities. Int. J. Hyg. Environ. Health 2016, 219, 372-379. [CrossRef] [PubMed]

19. Walser, S.M.; Gerstner, D.G.; Brenner, B.; Bünger, J.; Eikmann, T.; Janssen, B.; Kolb, S.; Kolk, A.; Nowak, D.; Raulf, M.; et al. Evaluation of exposure-response relationships for health effects of microbial bioaerosols-A systematic review. Int. J. Hyg. Environ. Health 2015, 218, 577-589. [CrossRef] [PubMed]

20. Basu, S.; Poole, J.; Frost, G.; Fox, D. Developing a questionnaire to assess the health effects of bioaerosols. Occup. Med. 2018, 68, 448-453. [CrossRef] [PubMed]

21. Van Kampen, V.; Sander, I.; Liebers, V.; Deckert, A.; Neumann, H.D.; Buxtrup, M.; Willer, E.; Felten, C.; Jäckel, U.; Klug, K.; et al. Concentration of bioaerosols in composting plants using different quantification methods. Ann. Occup. Hyg. 2014, 58, 693-706.

22. UNI EN 13098 Guidelines for Measurement of Airborne Microorganisms and Endotoxin; UNI Ente Italiano di Normazione: Milan, Italy, 2019.

23. Edmonds, J.M. Efficient methods for large-area surface sampling of sites contaminated with pathogenic microorganisms and other hazardous agents: Current state, needs, and perspectives. Appl. Microbiol. Biotechnol. 2009, 84, 811-816. [CrossRef]

24. Dacarro, C.; Grignani, E.; Lodola, L.; Grisoli, P.; Cottica, D. Proposed microbiological indexes for the assessment of air quality in buildings. Giornale Italiano di Medicina del Lavoro ed Ergonomia 2000, 22, 229-235.

25. Ministry of the Environment and Protection of the Territory and the Sea. Regolamento Recante i Criteri Operativi e le Procedure Autorizzative Semplificate per il Compostaggio di Comunità di Rifiuti Organici ai Sensi dell'articolo 180, Comma 1-octies, del Decreto Legislativo 3 aprile 2006, n.152, così come introdotto dall'artic; Gazzetta Ufficiale della Repubblica Italiana: Rome, Italy, 2011.

26. Ministry of Labour Decreto Legislativo 81/08, Testo Unico sulla salute e Sicurezza sul Lavoro; Gazzetta Ufficiale della Repubblica Italiana: Rome, Italy, 2008.

27. Vimercati, L.; Baldassarre, A.; Gatti, M.F.; De Maria, L.; Caputi, A.; Dirodi, A.A.; Cuccaro, F.; Bellino, R.M. Respiratory health in waste collection and disposal workers. Int. J. Environ. Res. Public Health 2016, 13, 631. [CrossRef]

28. de Meer, G.; Heederik, D.; Wouters, I.M. Change in airway responsiveness over a workweek in organic waste loaders. Int. Arch. Occup. Environ. Health 2007, 80, 649-652. [CrossRef]

29. Heldal, K.K.; Madsø, L.; Eduard, W. Airway inflammation among compost workers exposed to actinomycetes spores. Ann. Agric. Environ. Med. 2015, 22, 253-258. [CrossRef] [PubMed]

30. Heldal, K.K.; Halstensen, A.S.; Thorn, J.; Eduard, W.; Halstensen, T.S. Airway inflammation in waste handlers exposed to bioaerosols assessed by induced sputum. Eur. Respir. J. 2003, 21, 641-645. [CrossRef] [PubMed]

31. Gaviria-Figueroa, A.; Preisner, E.C.; Hoque, S.; Feigley, C.E.; Norman, R.S. Emission and dispersal of antibiotic resistance genes through bioaerosols generated during the treatment of municipal sewage. Sci. Total Environ. 2019, 686, 402-412. [CrossRef] [PubMed]

32. Humbal, C.; Joshi, S.K.; Trivedi, U.K.; Gautam, S. Evaluating the colonization and distribution of fungal and bacterial bio-aerosol in Rajkot, western India using multi-proxy approach. Air Qual. Atmos. Health 2019, 12, 693-704. [CrossRef]

33. UNI CEN/TS 16115-1 Measurement of Bioaerosols. Part 1: Determination of Moulds Using Filter Sampling Systems and Culture-Based Analyses; UNI Ente Italiano di Normazione: Milan, Italy, 2011. 
34. Ausschuss für Biologische Arbeitsstoffe (ABAS)TRBA 400, Handlungsanleitung zur GEFÄHRDUNGSBEURTEILUNG und für die Unterrichtung der Be-schäftigten bei Tätigkeiten mit Biologischen Arbeitsstoffen; Bundesanstalt für Arbeitsschutz und Arbeitsmedizin (BAuA): Berlin, Germany, 2018.

35. Rao, C.Y.; Burge, H.A.; Chang, J.C.S. Review of Quantitative Standards and Guidelines for Fungi in Indoor Air. J. Air Waste Manag. Assoc. 1996, 46, 899-908. [CrossRef]

36. UK Environment Agency. Technical Guidance Note-M9 Environmental Monitoring of Bioaerosols at Regulated Facilities; UK Environment Agency: Rotherham, UK, 2018.

37. Gutarowska, B.; Skóra, J.; Stępień, Ł.; Szponar, B.; Otlewska, A.; Pielech-Przybylska, K. Assessment of microbial contamination within working environments of different types of composting plants. J. Air Waste Manag. Assoc. 2015, 65, 466-478. [CrossRef]

38. Pinckard, J.K.; Rosenbluth, D.B.; Patel, K.; Dehner, L.P.; Pfeifer, J.D. Pulmonary hyalinizing granuloma associated with Aspergillus infection. Int. J. Surg. Pathol. 2003, 11, 39-42. [CrossRef]

39. Soubani, A.O.; Chandrasekar, P.H. The clinical spectrum of pulmonary aspergillosis. Chest 2002, 121, 1988-1999. [CrossRef]

40. Person, A.K.; Chudgar, S.M.; Norton, B.L.; Tong, B.C.; Stout, J.E. Aspergillus niger: An unusual cause of invasive pulmonary aspergillosis. J. Med. Microbiol. 2010, 59, 834-838. [CrossRef]

41. Poole, C.J.M.; Wong, M. Allergic bronchopulmonary aspergillosis in garden waste (compost) collectors-occupational implications. Occup. Med. 2013, 63, 517-519. [CrossRef]

42. Mbareche, H.; Veillette, M.; Dubuis, M.È.; Bakhiyi, B.; Marchand, G.; Zayed, J.; Lavoie, J.; Bilodeau, G.J.; Duchaine, C. Fungal bioaerosols in biomethanization facilities. J. Air Waste Manag. Assoc. 2018, 68, 1198-1210. [CrossRef] [PubMed]

43. Nasir, Z.A.; Rolph, C.; Collins, S.; Stevenson, D.; Gladding, T.L.; Hayes, E.; Williams, B.; Khera, S.; Jackson, S.; Bennett, A.; et al. A controlled study on the characterisation of bioaerosols emissions from compost. Atmosphere 2018, 9, 379. [CrossRef]

44. Tourlousse, D.M.; Ahmad, F.; Stedtfeld, R.D.; Seyrig, G.; Duran, M.; Alm, E.W.; Hashsham, S.A. Detection and Occurrence of Indicator Organisms and Pathogens. Water Environ. Res. 2008, 80, 898-928. [CrossRef]

45. Shneider, J.; Nagi, C.; Read, B. EU Air Quality Policy and WHO Guideline Values for Health. 2014. Available online: https://www.europarl.europa.eu/RegData/etudes/STUD/2014/536285/IPOL_STU(2014)536285_EN. pdf (accessed on 16 April 2020).

46. Duquenne, P.; Ambroise, D.; Görner, P.; Clerc, F.; Greff-Mirguet, G. Exposure to airborne Endotoxins among sewer workers: An exploratory study. Ann. Occup. Hyg. 2014, 58, 283-293.

47. Madsen, A.M.; Frederiksen, M.W.; Bjerregaard, M.; Tendal, K. Measures to reduce the exposure of waste collection workers to handborne and airborne microorganisms and inflammogenic dust. Waste Manag. 2020, 101, 241-249. [CrossRef]

48. Currie, S.L.; Beattie, T.K.; Knapp, C.W.; Lindsay, D.S.J. Legionella spp. in UK composts-a potential public health issue? Clin. Microbiol. Infect. 2014, 20, O224-O229. [CrossRef]

49. Casati, S.; Conza, L.; Bruin, J.; Gaia, V. Compost facilities as a reservoir of Legionella pneumophila and other Legionella species. Clin. Microbiol. Infect. 2010, 16, 945-947. [CrossRef]

50. Steere, A.C. Lyme disease. N. Engl. J. Med. 2001, 345, 115-125. [CrossRef]

51. Levine, O.S.; Levine, M.M. Houseflies (Musca domestica) as Mechanical Vectors of. Rev. Infect. Dis. 1991, 13, 688-696. [CrossRef]

52. Bünger, J.; Antlauf-lammers, M.; Schulz, T.G.; Westphal, G.A.; Müller, M.M.; Ruhnau, P.; Hallier, E.; Hamburg, D. Health complaints and immunological markers of exposure to bioaerosols among biowaste collectors and compost workers. Occup. Environ. Med. 2000, 57, 458-464. [CrossRef] [PubMed]

(C) 2020 by the authors. Licensee MDPI, Basel, Switzerland. This article is an open access article distributed under the terms and conditions of the Creative Commons Attribution (CC BY) license (http://creativecommons.org/licenses/by/4.0/). 